\title{
Protective effects of polyamines on regulation of senescence in spray carnation cut flowers (Dianthus caryophyllus'Spotlight')
}

\author{
Mahnaz KARIMI $^{1 *}$, Fateme AKBARI ${ }^{1}$, Ayoub HEIDARZADE ${ }^{2}$
}

Received May 07, 2017; accepted November 08, 2017.

Delo je prispelo 07. maja 2017, sprejeto 08. novembra 2017.

\begin{abstract}
This study was conducted to evaluate the effect of three polyamines (PAs) on antioxidants capacity, free radical scavenging and vase life improvement of spray carnation cut flowers. Hence, the cut flowers were dipped in different concentrations (0, 1, 2 and $3 \mathrm{mmol})$ of putrescine (Put), spermidine (Spd) and spermine (Spm) for $24 \mathrm{~h}$. After treatment, the cut flowers were placed in distilled water and kept at $20{ }^{\circ} \mathrm{C} \pm 2{ }^{\circ} \mathrm{C}, 70-80 \% \mathrm{RH}$. All concentrations of Put treatment improved the vase life of cut spray carnation flowers as compared to control. The highest positive influence on vase life (with 13 days) was related to $2 \mathrm{mmol}$ Put treatments. Result showed that applying Put and Spm treatments at 1 or 2 mmol concentration significantly minimized the percentage of mass loss compared to the control. A significant inhibition of anthocyanin degradation was observed with Put 1 or $2 \mathrm{mmol}$ and Spm $1 \mathrm{mmol}$ Significantly higher activities of catalase and DPPH radical scavenging activity were observed in petals when cut carnations were treated with $1 \mathrm{mmol}$ Put. It can be concluded that application of polyamines such as putrescine can play a key role to prevent or delay deterioration in cut flowers.
\end{abstract}

Key words: anthocyanin; catalase activity; cut flowers; polyamines; vase life

\author{
IZVLEČEK \\ ZAŠČITNI UČINKI POLIAMINOV NA \\ URAVNAVANJE SENESCENCE REZANIH \\ MNOGOCVETNIH NAGELJČKOV (Dianthus \\ caryophyllus'Spotlight')
}

$\mathrm{V}$ raziskavi je bil ovrednoten vpliv treh poliaminov (PAs) na antioksidacijsko sposobnost, odpravljanje prostih radikalov in izboljšanje trajanja rezanih večcvetnih nageljčkov. Odrezani poganjki $\mathrm{s}$ cvetovi so bili izpostavljeni različnim koncentracijam $(0,1,2$ in $3 \mathrm{mmol})$ putrescina (Put), spermidina (Spd) in spermina (Spm) za 24 h. Po obravnavanju so bile odrezane rastline premeščene $\mathrm{v}$ destilirano vodo pri $20^{\circ} \mathrm{C} \pm 2{ }^{\circ} \mathrm{C}, 70-80 \% \mathrm{RH}$. Vse koncentracije putrescina so podaljšale trajanje rezanega cvetja $\mathrm{v}$ primerjavi $\mathrm{s}$ kontrolo. Največji pozitivni učinek na trajanje cvetja (13 dni) je imelo obravnavanje z 2 mmol putrescina. Rezultati so pokazali, da je uporaba putrescina in spermina $\mathrm{v}$ koncentracijah 1 ali $2 \mathrm{mmol}$ značilno zmanjšala upad mase cvetja $\mathrm{v}$ primerjavi s kontrolo. Pri obravnavanjih $\mathrm{z} 1$ ali $2 \mathrm{mmol}$ putrescina in $1 \mathrm{mmol}$ spermina je bilo opaženo značilno zmanjšanje razgradnje antocianina. $\mathrm{V}$ venčnih listih rezanih nageljčkov, tretiranih $\mathrm{z}$ $1 \mathrm{mmol}$ putrescina sta bili značilno povečani aktivnosti katalaze in DPPH nevtralizacije radikalov. Zaključimo lahko, da ima lahko uporaba poliaminov kot je putrescin ključno vlogo pri preprečevanju in odlogu propadanja rezanega cvetja.

Ključne besede: antocianin; aktivnost katalaze; rezano cvetje; trajanje; poliamini

\section{INTRODUCTION}

Recently, spray type of cut carnation flowers have become more popular (Hanks et al., 2015). Hence its postharvest senescence is a major limitation to the marketing and considerable efforts have been devoted to developing postharvest treatments to extend the marketing period (Nichols, 1977; Rattanawisalanona et al., 2003, Karimi et al., 2012). On the other hand the main challenge of florists in the global flower trading is the quality of cut flowers (Seglie et al., 2012). Polyamines (PAs), putrescine, spermidine and spermine

1 Department of Horticultural Sciences, Faculty of agronomy Sciences, Sari Agricultural Sciences and Natural Resources University, P.O.BOX578, Sari, Iran ; *Corresponding author: karimi.sanru@gmail.com

2 Department of Agronomy, Faculty of agronomy Sciences, Sari Agricultural Sciences and Natural Resources University, P.O.BOX- 578, Sari, Iran 
are low molecular weight compounds and present naturally in all living organisms (Kao, 1997). Many studies well documented the role of PAs as antisenescent agents in reduction of respiration rate, ethylene production and retard color changes and increase flowers vase life (Niklas et al. 1998; Valero et al., 2002; Genk et al., 2009; Rani \& Singh, 2014; Tiburcio e al., 2014). The polyamine and ethylene biosynthesis pathways are interrelated, due to the competition on $\mathrm{S}$ - adenosylmethionine (SAM) (Bouchereau et al., 1999). Also, ethylene has been shown to play an important role in flower senescence regulation. Treatment of carnation cut flowers with ethylene inhibitors significantly extended vase life and CAT, SOD and POD enzyme activity (Hunter et al., 2004; Karimi et al., 2012; Karimi et al., 2013). Meanwhile, more studies suggested that treatment with PAs significantly improved fresh mass, uptake of vase solution, flower opening, vase life and more parameters of ornamental plants (Pandey et al., 2000; Rubinowska \& Miachałek, 2009; Kandil et al., 2011; Mahgoub et al., 2011; Hosseini Farahi et al., 2013; Ataii et al., 2015).
The effects of different concentrations of putrescine on flower characters, total carbohydrates and photosynthetic pigments of Chrysanthemum were investigated by Kandil et al. (2011). They concluded that all flower characters were significantly increased by foliar application of putrescine at different concentrations (100, 200 and 300 ppm). In this regards, Mahgoub et al. (2011) reported that PAs delayed senescence and improved vase life of cut Dahlia pinnata Cav. by improving membrane stability of cells. In another related study Ataii et al. (2015) evaluated the effects of different levels of exogenous putrescine on vase life of cut Lisianthus flowers. They suggested that Put treatment enhanced the activities of antioxidant system (catalase and ascorbate peroxidase) and limited the accumulation of $\mathrm{H}_{2} \mathrm{O}_{2}$. Hence according to the importance of vase life of cut flowers, the present study was conducted to investigate the effects of exogenous application of different PAs on maintaining quality, extending vase life and antioxidant capacity of spray carnation.

\section{MATERIALS AND METHODS}

In order to evaluated the protective effects of polyamines on regulation of senescence in cut sprayed carnation (Dianthus caryophyllus'Spotlight') a potted experiment was conducted in Sari Agricultural Sciences and Natural Resources University in north of Iran during the spring of 2016. The uniform cut flowers of spray carnation (Dianthus caryophyllus 'Spotlight') were obtained from a commercial grower and packed in plastic bags, and transferred to the laboratory immediately. At purchasing time, the flowers were harvested commercially at the usual flowering time (the first flower of the six to eight buds on the stem was almost fully opened). The stems were shortened up to $40 \mathrm{~cm}$, immersed with their cut ends at $0,1,2$ and $3 \mathrm{mM}$ diamine putrescine (Put), tetramine spermine (Spm) and triamine spermidine (Spd) solutions for $24 \mathrm{~h}$. After treatment, the cut flowers were placed in a $500 \mathrm{ml}$ flask with $400 \mathrm{ml}$ of distilled water and kept at $20^{\circ} \mathrm{C} \pm 2{ }^{\circ} \mathrm{C}$, $70-80 \%$ relative humidity, and $12 \mathrm{~h}$ photoperiod with $15 \mu \mathrm{mol} \mathrm{m} \mathrm{m}^{-2} \mathrm{~s}^{-1}$ irradiance from warm fluorescent lamps throughout the experiment.

\subsection{Evaluation of vase life and fresh mass loss}

Vase life and fresh mass loss were determined as the time to wilting of more than one third of the flowers in each pot (Karimi et al., 2012). The fresh mass of each flower (stem + flower) was expressed relative to the initial fresh mass to represent the percentage of mass.

\subsection{Measurement of anthocyanin concentration}

Anthocyanin content of the petals was determined on day 5 (when the vase life of the control flower was terminated). Petal slices were extracted with $100 \%$ methanol containing $1 \% \mathrm{HCl}$ at $4{ }^{\circ} \mathrm{C}$ overnight. The absorbance of the extract was measured at $530-700 \mathrm{~nm}$ with a spectrophotometer (3600 UV/ Vis, UNICO, USA) (Paliyathet al., 2008).

\subsection{Evaluation of 1,1-dyphenyl-2-picrylhydrazyl (DPPH) scavenging activity}

At first $4 \mathrm{mg}$ DPPH was dissolved in $100 \mathrm{ml}$ of methanol. The stock solution of the flower extract was prepared in $95 \%$ methanol to achieve the desired concentration and to $0.2 \mathrm{ml}$ of sample $2 \mathrm{ml}$ of DPPH was added and the solution was incubated for $20 \mathrm{~min}$. Absorbance was measured against reagent blank at $517 \mathrm{~nm}$ spectro-photometrically (3600 UV/ Vis, UNICO, USA) (Miliauskas et al., 2004). The IC 50 value of the sample, which is the concentration of sample required to inhibit $50 \%$ of the DPPH free radical, was calculated using log dose inhibition curve (Sidduraju et al., 2002). The ability of the essential oil to scavenge DPPH radical was calculated as percent inhibition by the following equation: Percent inhibition $=[($ Acontrol - Asample $) /$ Acontrol $] \times 100$

\subsection{Catalase enzyme assays (CAT; EC 1. 11.1.6)}

Catalase (CAT) activities assay were quantified spectrophotometrically (Aebi, 1983). The reaction mixture contained $15 \mathrm{mmol} \mathrm{H}_{2} \mathrm{O}_{2}$, up to $100 \mu \mathrm{l}$ of homogenate 
(7 mg protein $\mathrm{ml}^{-1}$ ) with $0.2 \%(\mathrm{v} / \mathrm{v})$ Triton $\mathrm{X}-100$ in $50 \mathrm{mmol}$ potassium phosphate buffer $(\mathrm{pH} 7.0)$

\subsection{Experimental design and statistical analysis}

This experiment was conducted in a completely randomized design with four replications. Results were analyzed using SAS software. Mean comparisons to identify significant difference between treatments were performed using the least significant difference (LSD).

\section{RESULTS}

\subsection{Vase life determination}

The Put at all tested concentrations improved the vase life of cut spray carnation flowers as compared with control (Distilled water). The best results were achieved with the 2 mmol Put variant/ 13 days compared to control variant/ 9 days. However, there were no significant differences between $1 \mathrm{mmol}$ spermine and 1 or 2 mmol Put treatment (Fig. 1).

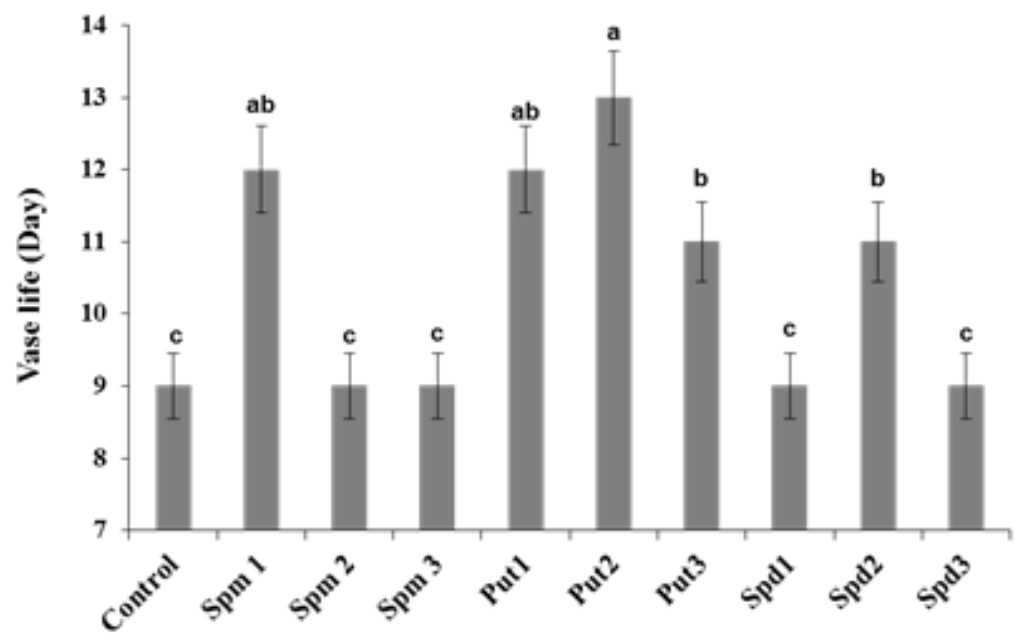

Figure 1: Vase life of cut carnation flowers in response to pretreatment with different concentrations of polyamines Put, Spm and Spd at 0, 1, 2 and 3 mmol. Diversified letters indicate significant differences $(p<0.05)$.

\subsection{Anthocyanin content}

A significant inhibition of anthocyanin degradation was observed with Put 1 or $2 \mathrm{mmol}$ and Spm $1 \mathrm{mmol}$. There were no significant difference between Spm 2, Spd 1 or $3 \mathrm{mmol}$, and control (Fig. 2).

\subsection{Fresh mass loss}

Result showed that applying Put and Spm treatments at 1 or 2 mmol dose significantly minimized the mass loss compared to control until the ninth day (Tab. 1). However, both 2 and $3 \mathrm{mmol}$ treatments affected more positively the fresh mass than $1 \mathrm{mmol}$ treatment. The lowest percent of mass loss on $9^{\text {th }}$ day (when the vase life of the control flowers was terminated) was obtained by $2 \mathrm{mmol}$ Put treatment (with $12.82 \%$ ). However, the results of the control flowers showed the maximum percentage of mass loss $(48.32 \%)$ on day 9 (Tab. 1$)$. 


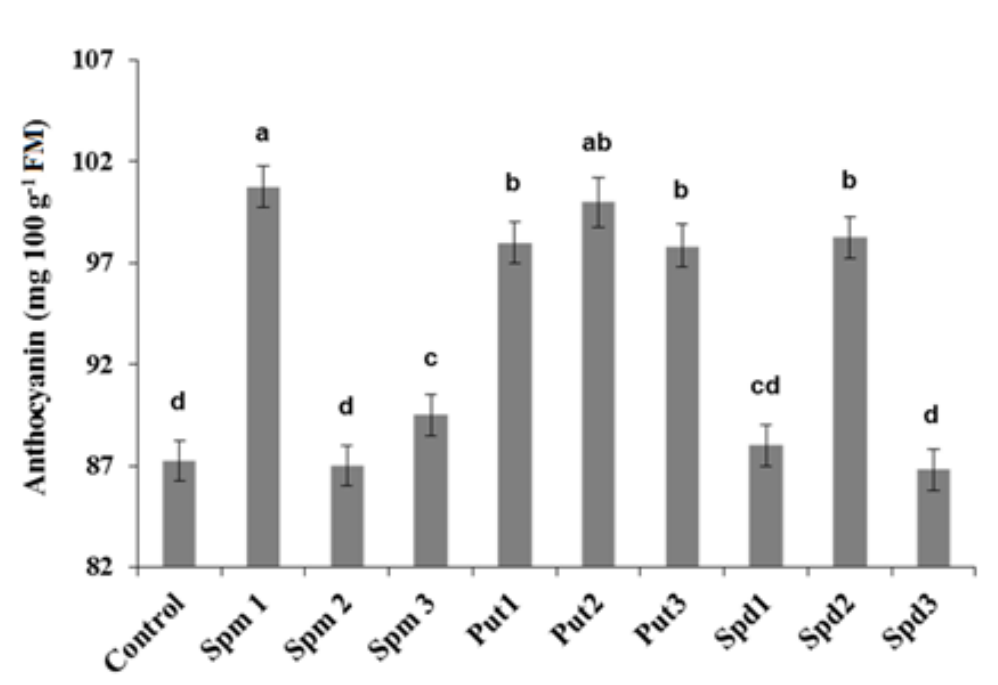

Figure 2: Anthocyanin contentment of cut carnation flowers in response to pretreatment with different concentrations of Put, Spm and Spd at 0, 1, 2 and $3 \mathrm{mmol}$. Diversified letters indicate significant differences $(p<0.05)$

\subsection{Effect of polyamines on antioxidant metabolism}

Significantly higher activities of CAT and DPPH radical scavenging activity were observed in petals when cut carnations were treated with $1 \mathrm{mmol}$ Put. Although there were no significant differences between 1 and 2 mmol Put and 1 mmol Spm (Tab. 1).

Table 1: Means \pm standard errors of fresh mass loss, DPPH scavenging activity, catalase activity of cut carnation flowers in response to pretreatment with different concentrations of Put, Spm and Spd at 0, 1, 2 and 3 mmol

\begin{tabular}{|c|c|c|c|c|}
\hline \multicolumn{2}{|c|}{ Treatments (mmol) } & $\begin{array}{l}\text { Fresh Mass Loss } \\
(\%) \\
9^{\text {th }} \text { day }\end{array}$ & $\begin{array}{l}\text { DPPH scavenging } \\
\text { activity }(\mathrm{mg} / \mathrm{ml})\end{array}$ & 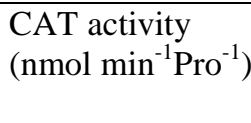 \\
\hline CONTROL & 0 & $48.32 \pm 2.07 \mathrm{a}$ & $0.21 \pm 0.26 \mathrm{~d}$ & $0.50 \pm 0.39 \mathrm{~d}$ \\
\hline \multirow{3}{*}{$P U T$} & $l$ & $11.12 \pm 4.31 \mathrm{c}$ & $0.49 \pm 0.17 \mathrm{a}$ & $1.24 \pm 0.25 \mathrm{a}$ \\
\hline & 2 & $12.82 \pm 4.01 \mathrm{c}$ & $0.47 \pm 0.17 \mathrm{a}$ & $1.21 \pm 0.25 \mathrm{a}$ \\
\hline & 3 & $41.32 \pm 2.24 \mathrm{~A}$ & $0.21 \pm 0.26 b$ & $0.76 \pm 0.32 \mathrm{c}$ \\
\hline \multirow{3}{*}{$S P M$} & 1 & $42.12 \pm 2.21 \mathrm{a}$ & $0.47 \pm 0.17 \mathrm{a}$ & $1.20 \pm 0.26 \mathrm{a}$ \\
\hline & 2 & $47.30 \pm 2.09 \mathrm{~A}$ & $0.39 \pm 0.19 b c$ & $0.98 \pm 0.28 b$ \\
\hline & 3 & $46.32 \pm 2.11 \mathrm{a}$ & $0.20 \pm 0.26 \mathrm{~d}$ & $0.59 \pm 0.36 \mathrm{~d}$ \\
\hline \multirow{3}{*}{$S P D$} & 1 & $44.18 \pm 2.16 \mathrm{a}$ & $0.22 \pm 0.25 \mathrm{~d}$ & $0.58 \pm 0.37 \mathrm{~d}$ \\
\hline & 2 & $24.85 \pm 2.88 \mathrm{~b}$ & $0.34 \pm 0.19 \mathrm{c}$ & $0.99 \pm 0.28 b$ \\
\hline & 3 & $44.11 \pm 2.16 \mathrm{~A}$ & $0.39 \pm 0.20 b c$ & $1.04 \pm 0.27 b$ \\
\hline
\end{tabular}

*Means within each column followed by different letters are significantly different $(\mathrm{p}=0.05)$

\section{DISCUSSION}

The obtained results indicate that polyamines at 1 or 2 concentrations improved the vase life of cut spray carnation flowers respectively compared with the control. Meanwhile the highest vase life duration belonged to $1 \mathrm{mmol}$ Put treatment. In plant cells, the Put, Spd and Spm constitute the major polyamines 
(PAs). The increase in flowers vase life by using PAs may be due to inhibiting ethylene production, because, the polyamine and ethylene synthesis pathways are interrelated, which results from the competition for the common precursor, S - adenosylmethionine (SAM); hence, one synthesis pathway is stimulated and the other one inhibited (Bouchereau et al., 1999). The physiological effects of polyamines and ethylene on senescence are the opposite to each other (Fuhrer et al., 1982; Winer \& Apelbaum, 1986). The time of the onset of ethylene production and the amount of ethylene produced in the flower vary with the carnation cultivar (Nukui et al., 2004). In our previous studies using ethylene inhibitors increased the vase life of carnation flowers (Karimi et al. 2012; Karimi et al., 2013; Hassanpour et al., 2013). Lee et al. (1997) reported that treatment of $1 \mathrm{mmol}$ spermine extended the vase life of carnation flowers and reduced ethylene production. The highest vase life of Rosa hybrida 'Dolce vita' was obtained in solutions containing $0.5 \mathrm{mmol}$ spermidine and also in solutions containing $1 \mathrm{mmol}$ spermine (Hosseini Farahi et al., 2012). Color fading and discoloration are important factors in determining visual quality of flowers and in many cases they are the main reasons for determination of post-production quality (Basra, 2000). The major types of pigments contributing to the color of the flowers are carotenoids and anthocyanins (Basra, 2000). The improvement of petal color expression is at least partially due to the increase in anthocyanin contents. Ethylene has been known to cause petal color fading. Pretreatment with PAs could reduce ethylene production in cut flowers, which is an important factor involved in retaining bract discoloration. During senescence there is an overproduction of free radicals such as superoxide anion $\left(\mathrm{O}^{-}\right.$ ${ }^{2}$ ), hydroxyl radicals $(\mathrm{OH})$ and hydrogen peroxide $\left(\mathrm{H}_{2} \mathrm{O}_{2}\right)$, which may cause damage, leading to cell death. The harmful free radicals are controlled and balanced by antioxidant systems (Khan, 2006). Several enzymes such as SOD, CAT and POD are involved in the scavenging of free radicals in the plant system (Celikel \& Van Doorn, 1995). Larrigaudiere et al. (2004) suggested that ethylene was involved in ROS production. Our results showed that polyamines (1 or $2 \mathrm{mmol}$ Put and Spm) treated cut flowers had significantly higher CAT and DPPH radical scavenging activity compared with the control (Tab. 1). This study on polyamines can be understood not only as experimental evidence confirming the hypothesis of a link between ethylene and free radicals generation in senescence, but also as a key to the development of adequate methods to prevent or delay deterioration in cut flowers.

Therefore, it could be concluded that polyamines treatments may be good candidates for extending vase life, maintaining the visual quality of flowers. The treatment with Put and Spm (1 and $2 \mathrm{mmol}$ ) retarded the decrease fresh mass loss and anthocyanin degradation and increased the CAT and DPPH radical scavenging activity measured in petals.

\section{REFERENCES}

Ataii D., Naderi R. \& Khandan-Mirkohi A. (2015). Exogenous putrescine delays senescence of Lisianthus cut flowers, Journal of Ornamental plant, 5 (3), 167-174.

Basra, A.S. (2000). Plant growth regulator in agriculture and horticulture, Part 5. Food products press, 5, 147-165.

Bouchereau, A., Aziz, A, Larher, F, \& Martin-Ttanguy, J. (1999). Polyamines and environmental challenges: recent development, Plant Science, 140, 103-125. doi:10.1016/S0168-9452(98)00218-0

Celikel, F.G., \& Van Doorn, W.G. (1995). Solute leakage lipid peroxidation and protein degradation during the senescence of Iris tepals, Physiologia Plantarum, 94, 515-521. doi:10.1111/j.13993054.1995.tb00962.x

Fuhrer, J., Kaur-Sawhney, R., Shin, L., \& Galstons, A.W. (1982). Effects of exogenous 1,3diaminopropane and spermidine on senescence of oat leaves, Plant Physiology, 70, 1597-1600. doi:10.1104/pp.70.6.1597

Geng, X.M., Liu, J., Lu, J.G., Hu, F.R, \& Okubo, H. (2009). Effect of cold storage and different pulsing treatments on postharvest quality of cut OT Lilly 'Mantissa' flowers, Journal of the Faculty of Agriculture, Kyushu University, 54, 41-45.

Hassanpour Asil, M., Karimi, M., \& Zakizadeh, H. (2013). 1-MCP Improves the Postharvest Quality of Cut Spray Carnation (Dianthus caryophyllus L.) 'Optima' Flowers. Horticulture, Environment, and Biotechnology, 54 (1), 58-62. doi:10.1007/s13580013-0044-8

Hosseini Farahi, M., Khalighi, A., kavoosi B., \& Aboutalebi, A. (2012). Morphological responses and vase life of Rosa hybrida cv. Dolcvita to polyamines spray in hydroponic system, Annals of Biological Research, 3 (10), 4854-4859.

Hunter, D.A., Yi, M., Xu, X. Reid, M.S. (2004). Role of ethylene in perianth senescence of daffodil 
(Narcissus pseudonarcissus L. 'Dutch Master'), Postharvest Biology and Technology, 32, 269- 280. doi:10.1016/j.postharvbio.2003.11.013

Kandil, M.M., El-Saady, M.B., Mona, H.M., Afaf, M.H. \& Iman, M.E. (2011). Effect of putrescine and uniconazole treatments on flower characters and photosynthetic pigments of Chrysanthemum indicum L. American Journal of Plant Science, 7(3), 399-408.

Kao, C.H. (1997). Physiological significance of stressinduced changes in polyamines in plants, Botanical Bulletin- Academia Sinica, 38, 141-144.

Karimi, M., Hassanpour Asil, M., Nematzadeh, G.H., \& Zakizadeh, H. (2012). Role of anti-ethylene treatments on ethylene production and antioxidant activities in cut spray carnation, Journal of Fruit and Ornamental Plant Research, 20(2), 173-182. doi:10.2478/v10290-012-0026-4

Karimi, M., Hassanpour Asil, M. \& Zakizadeh, H. (2013). Increasing plant longevity and associated metabolic events in potted carnation (Dianthus caryophyllus. 'Clove Pink'), Brazilian Journal of Plant Physiology, 24(4), 247- 252. doi:10.1590/S1677-04202012000400003

Khan, N.A. (2006). Ethylene action in plants. Springer. Springer-Verlag Berlin Hei-delberg, Netherlands, pp. 206. doi:10.1007/978-3-540-32846-9

Larrigaudiere, C., Vilaplana, R., Soria, Y., \& Recasens, I. (2004). Oxidative behaviour of Blanquilla pears treated with 1-methylcyclopropene during cold storage, Journal of the Science of Food and Agriculture, 84, 1871-1877. doi:10.1002/jsfa. 1850

Larsen, P., Woltering, E. \& Woodson, W. (1993). Ethylene and interorgan signalling in flowers following pollination, Eds, J Raskin \& J Shultz, Plant Signals in interactions with other organisms, American Society of Plant Physiology, pp, 112122.

Lee, M., Lee, S.H. \& Park, K.Y. (1997). Effects of spermine on ethylene biosynthesis in cut carnation (Dianthus caryophyllus L.) flowers during senescence, Journal of Plant Physiology, 151, 6873. doi:10.1016/S0176-1617(97)80038-7

Mahgoub, M.H., Abd El Aziz N.G. \& Mazhar, M.A. (2011). Response of Dahlia pinnata L. plant to foliar spray with Putrescine and Thiamine on growth, flowering and photosynthetic pigments, American- Eurasian Journal of Agriculture and Environment Sciences, 10(5), 769-775.

Mayak, S., Legge, R.L. \& Thompson J.E. (1983). Superoxide radical production by microsomal membranes from senescing carnation flowers: an effect on mem-brane fluidity, Phytochemist, 11, 1375-1380. doi:10.1016/S0031-9422(00)84018-2

Miliauskas, G., Venskutonis, P. R. \& Vanbeek, T.A. (2004). Screening of radical scavenging activity of some medicinal and aromatic plant extracts, Food Chemistry, 85, 231-237. doi:10.1016/j.foodchem.2003.05.007

Niklas, A., Butowit, R., Jazdziewska, E. \& MajewskaSawka A. (1998). Polyamines in the plant cell: synthesis, action mechanisms, and functions, Postępi Biologii Komórki, 25, 22-49.

Nukui, H., Kudo, S., Yamashita, A. \& Satoh, S. (2004). Repressed ethylene production in the gynoecium of long-lasting flowers of the carnation 'White Candle': Role of gynoecium in carnation flower senescence, Journal of Experimental Botany, 55, 641-650. doi:10.1093/jxb/erh081

Rani, P. \& Singh, N. (2014). Senescence and Postharvest Studies of Cut Flowers: A Critical Review, Pertanika Journal of Tropical Agricultural Science, 37(2), 159-201.

Rubinowska, K. \& Miachałek, W. (2009). Influence of putrescine on leaf senescence of Helianthus annuus potted plants. Horticulture and Landscape Architecture, 30, 57-65.

Seglie, L., Spadaro, D., Trotta, F., Devecchi, M., Gullino, M.L. \& Scariot V. (2012). Use of 1methylcylopropene in cyclodextrin-based nanosponges to control grey mouldcaused by Botrytis cinerea on Dianthus caryophyllus cut flowers, Postharvest Biology and Technology, 64, 55-57. doi:10.1016/j.postharvbio.2011.09.014

Sidduraju, P., Mohan, P. \& Becker K. (2002). Studies on the antioxidant activity of Indian laburnum (Cassia fistula L): a preliminary assessment of crude extracts from stem bark, leaves, flowers and fruit pulp, Food Chemistry, 79, 61-67. doi:10.1016/S0308-8146(02)00179-6

Tang, X., Gome, A., Bhatia, A. \& William W. (1994). Pistil-specific and ethylene-regulated expression of 1 aminocyclopropane-1-carboxylate oxidase genes in petunia flowers, The Plant Cell, 6, 1227-1239. doi:10.1105/tpc.6.9.1227

Tiburcio, A.F., Altabella, T., Bitrián, M. \& Alcázar, R. (2014). The roles of polyamines during the lifespan of plants: from development to stress, Planta, 240(1), 1-18. doi:10.1007/s00425-014-2055-9

Valero, D., Martinez-Romero, D., Serrano, M. \& Riquelme, F. (1998). Influence ofpostharvest treatment with putrescine and calcium on endogenous polyamines,firmness and abscisic acid in lemon (Citrus lemon L. Burm cv. Verna), Journal 
Protective effects of polyamines ... carnation cut flowers (Dianthus caryophyllus'Spotlight')

of Agricultural and Food Chemistry, 46, 21022109. doi:10.1021/jf970866x

Winer, L. \& Apelbaum, A. (1986). Involvement of polyamines in the development and ripening of avocado fruits, Journal of Plant Physiology, 126, 223-233. doi:10.1016/S0176-1617(86)80024-4 